\title{
AMPHIBIANS OF PURNA WILDLIFE SANCTUARY, DANGS, GUJARAT
}

\author{
Manju Siliwal ${ }^{1}$, Shilpa Dhuru ${ }^{2}$, B. Suresh ${ }^{3}$, Y.M. Naik and \\ Bonny Pilo ${ }^{4}$ \\ Department of Zoology, Faculty of Science, The Maharaja \\ Sayajirao University of Baroda, Vadodara 390002 \\ Emails: ${ }^{1}$ manjusiliwal@ rediffmail.com, \\ ${ }^{2}$ shilpa_dhuru@hotmail.com, ${ }^{3}$ suved9@hotmail.com, \\ ${ }^{4}$ bonnypilo@satyam.net.in
}

Purna Wildlife Sanctuary is located between $20^{\circ} 51^{\prime}-21^{0} 21^{\prime} \mathrm{N}$ and $73^{\circ} 32^{\prime}-73^{\circ} 48^{\prime} \mathrm{E}$, falling under Dangs District in Gujarat. According to Champion and Seth (1968) vegetation of this Sanctuary could be classified as Moist teak forest $(3 \mathrm{~B} / \mathrm{C} 1 \mathrm{~b})$, Southern moist mixed deciduous forest $(3 \mathrm{~B} / \mathrm{C} 2)$ and bamboo brake (5/E9). Total area of the Sanctuary is $160.84 \mathrm{~km}^{2}$ with an average rainfall of $1600 \mathrm{~mm}$ per annum. The terrain is undulating with altitudinal variation from $130-1100 \mathrm{~m}$.

Purna Wildlife Sanctuary harbours diverse flora and fauna. However, faunal diversity of this Sanctuary remains poorly understood. Hence, a survey was carried out between 19 June and 9 July 2001. Amphibians encountered were identified in the field. Individuals whose identity could not be confirmed in the field were collected, photographed and were later identified by using standard references (Boulenger, 1890; Taylor, 1961; Daniel, 1975; Daniel \& Sekar, 1989; Bhatta, 1998; Pillai \& Ravichandran, 1999). Morphometric measurements were taken with the help of a vernier callipers to the nearest $0.1 \mathrm{~mm}$. Sex of the museum specimens was determined by dissecting the animal.

In the present study, nine species belonging to four families of Anura and one family of Apoda were recorded (Table 1). Out of these, one species, Sphaerotheca rufescens (Jordon, 1854) has not been previously reported from Gujarat. Voucher specimens have been deposited in the Department Museum, Department of Zoology, M.S. University of Baroda, Vadodara 390002. The details of collection, morphometry and field observations of the newly recorded species is given below.

Sphaerotheca rufescens (Jordon, 1854)

Material examined

One female, Bheskatri Range of Purna WLS, Gujarat, coll. M. Siliwal, MSU-AMP-20-1; one female, Bardipada Range of Purna WLS, Gujarat, coll. M. Siliwal, MSU-AMP-20-2.

\section{Measurements}

Snout-vent length $34.5-36.5 \mathrm{~mm}$; head length $9.0-13.0 \mathrm{~mm}$; head width 15.0-16.0mm; tibia length 10.0-12.0mm. Detailed measurements are given in Table 2.

\section{Field observations}

MSU-AMP-20-1 was collected at dusk time from a short-grass patch on the hill slopes near Gira fall. MSU-AMP-20-2 was collected from a puddle at $2000 \mathrm{hr}$ in Kalibel.

\section{Acknowledgement}

We thank the team 'Conservation of Rare and Endangered Biodiversity of Gujarat' (CREB) project for financial support and the members of CREB for assistance in field trips. Authors are thankful to Zoo Outreach Organisation/Wildlife Information Liaison Development Society, Coimbatore for providing the latest IUCN status of amphibians.

\section{References}

Bhatta, G.K. (1998). A field guide to the caecilians of the Western Ghats, India. Journal of Biosciences 23(1): 73-85.

Boulenger, G. A. (1890). Fauna of British India including Ceylon and Burma: Reptilia and Batrachia. London.

Amphibian C.A.M.P.-G.A.A. (In press). Status of South Asian Amphibians. Conservation Assessment and Management Plans and Global Amphibian Assessment Workshop 2002, 1-5 July 2002, Coimbatore, India.

Champion, H.G and S.K. Seth. (1968). A revised survey of the forest types of India. Government of India Press, New Delhi.

Daniel, J.C. (1975). Field guide to the amphibians of western India. Journal of the Bombay Natural History Society 72: 506-522.

Daniel, J.C. and A.G. Sekar (1989). Field guide to the amphibians of western India. Journal of the Bombay Natural History Society 86: 180-202.

Pillai, R.S., and M.S. Ravichandran (1999). Gymnophiona (Amphibian) of India - A taxonomic study. Records of Zoological Survey of India, Occasional Paper No. 170-173.

Taylor, E. (1961). Notes on Indian Ceacilians. Journal of the Bombay Natural History Society 58(2): 355-365.

${ }^{1}$ Present address: Wildlife Information Liaison Development Society, 29-1 Bharathi Colony, Peelamedu, Coimbatore, Tamil Nadu 641004, India 
Table 1. List of amphibians found in Purna Wildlife Sanctuary, Dangs, India

\begin{tabular}{|c|c|c|c|c|c|}
\hline Species & NE & NC & TN & RA & IUCN Status* \\
\hline \multicolumn{6}{|l|}{ Ichthyophiidae } \\
\hline Ichthyophis bombayensis Taylor 1960 & 34 & 4 & $\begin{array}{l}\text { MSU-AMP-23-1, } \\
\text { MSU-AMP-23-2, } \\
\text { MSU-AMP-23-3, } \\
\text { MSU-AMP-23-4 }\end{array}$ & Common & Critically Endangered \\
\hline \multicolumn{6}{|l|}{ Bufonidae } \\
\hline Bufo sp. & 2 & 2 & $\begin{array}{l}\text { MSU-AMP-21-1, } \\
\text { MSU-AMP-21-2 }\end{array}$ & Uncommon & - \\
\hline \multicolumn{6}{|l|}{ Microhylidae } \\
\hline Ramanella montana (Jerdon 1854) & 1 & 1 & MSU-AMP-12-3 & Uncommon & Near Threatened \\
\hline \multicolumn{6}{|l|}{ Ranidae } \\
\hline$\overline{\text { Hoplobatrachus tigerinus (Daudin 1803) }}$ & 4 & 1 & MSU-AMP-3-6 & Very Common & Least Concern \\
\hline Fejervariya limnocharis (Boie in: Wiegmann 1835) & 3 & 1 & MSU-AMP-2-4 & Common & Least Concern \\
\hline Fejervariya keralensis (Dubois, 1980) & 3 & 1 & MSU-AMP-4-3 & Common & Least Concern \\
\hline Tomopterna breviceps (Schneider 1799) & 2 & 1 & MSU-AMP-9-2 & Uncommon & Least Concern \\
\hline Sphaerotheca rufescens (Jerdon 1854) & 2 & 2 & $\begin{array}{l}\text { MSU-AMP-20-1, } \\
\text { MSU-AMP-20-2 }\end{array}$ & Uncommon & Least Concern \\
\hline \multicolumn{6}{|l|}{ Rhacophoridae } \\
\hline Polypedatus maculatus (Gray 1834) & 4 & 1 & MSU-AMP-10-4 & Very Common & Least Concern \\
\hline
\end{tabular}

NE - Number of specimen examined; NC - Number of specimen collected; TN - Tag number of collected specimen; RA - Relative abundance; * from C.A.M.P. G.A.A. (in press).

Table 2. Morphometry of Sphaerotheca rufescens (Jordon, 1854)

\begin{tabular}{|c|c|c|}
\hline Parameters & $\begin{array}{l}\text { Specimen } 1 \\
\text { (MSU-AMP-20-1) (mm) }\end{array}$ & $\begin{array}{l}\text { Specimen } 2 \\
\text { (MSU-AMP-20-2) (mm) }\end{array}$ \\
\hline Snout-vent length & 36.5 & 34.5 \\
\hline Head length & 13.0 & 9.0 \\
\hline Head width & 16.0 & 15.0 \\
\hline Length of snout & 2.0 & 2.0 \\
\hline Maximum length of eye & 4.5 & 4.5 \\
\hline Interorbital space & 3.0 & 3.0 \\
\hline Length of arm & 15.0 & 12.0 \\
\hline Tympanum & 2.0 & 2.0 \\
\hline Length of hand & 3.5 & 3.0 \\
\hline $1^{\text {st }}$ finger & 3.8 & 3.5 \\
\hline $2^{\text {nd }}$ finger & 5.5 & 4.8 \\
\hline $3^{\text {rd }}$ finger & 4.0 & 3.0 \\
\hline $4^{\text {th }}$ finger & 6.0 & 5.5 \\
\hline Length of leg & 40.0 & 38.0 \\
\hline Length of tibia & 12.0 & 10.0 \\
\hline Length of foot & 6.0 & 5.0 \\
\hline $1^{\text {st toe }}$ & 3.0 & 3.0 \\
\hline $2^{\text {nd }}$ toe & 4.5 & 4.0 \\
\hline $3^{\text {rd }}$ toe & 6.0 & 5.0 \\
\hline $4^{\text {th }}$ toe & 9.5 & 9.0 \\
\hline $5^{\text {th }}$ toe & 4.0 & 4.0 \\
\hline
\end{tabular}

Tibiotarsal articulation reaches tympanum 